\title{
Examining Patterns within Challenged or Banned Primary Elementary Books
}

\author{
John Holden Bickford ${ }^{1}$ \& Devanne Lawson ${ }^{2}$
}

1. Corresponding author

Eastern Illinois University, Charleston, Illinois, US.

E-mail: jbickford@eiu.edu

2. Carl Sandburg Elementary School, Charleston, Illinois, USA.

\section{Article Info}

Received: March 21, 2020

Revised: April 30, 2020

Accepted: May 16, 2020

\section{$10.46303 / j c s r .02 .01 .2$}

This is an Open Access article distributed under the terms of the CC BY-NC-ND 4.0 International license.

(https://creativecommons.org/licenses/bync-nd/4.0)

\section{How to cite}

Bickford, J. H., \& Lawson, D. R. (2020). Examining patterns within challenged or banned primary elementary books. Journal of Curriculum Studies Research, 2(1), 1638.

\section{https://doi.org/10.46303/jcsr.02.01.2}

\begin{abstract}
Public schools and public libraries often receive challengessuppression or removal requests-to particular books, which can lead the book being banned. Research has examined challenges to books with multicultural themes and individuals, noted that authors of color are disproportionally targeted, and recognized the remarkable number of challenges to books deemed to be classic. This qualitative content analysis research utilized both with inductive and deductive elements-open coding and axial coding-to examine challenged books intended for primary elementary students. The theoretical framework blended critical multiculturalism, gay and lesbian identity, and radical politics in children's literature. Findings included patterns based on era, frequency and location of challenge, demography of challenger, and oft-challenged themes, specifically sexuality (sexual reproduction and diverse sexualities), inappropriate humor, danger, death, racial and religious diversity, mysticism and wizardry, racially or culturally insensitive elements, concerning interpersonal dynamics, and evolution. Meaning is extracted for teachers, librarians, administrators, and researchers.

\section{KEYWORDS}

Education; Curriculum studies; Children's literature; Banned books; Challenged books; LGBTQ
\end{abstract}




\section{INTRODUCTION}

Leslea Newman's (1989) Heather has Two Mommies, in which homosexual characters first prominently appeared in American children's literature, ${ }^{1}$ sparked affirmation and condemnation. Newman's book was not the first nor the last to be challenged as inappropriate for young children. Though the process is determined locally, a challenged book is a formal attempt to remove or restrict access to a book from a library or school. A banned book results from a successful challenge, though repeated challenges do not enhance the outcome. Parents, citizen groups, elected officials, and school administrators often raise concerns about teachers' and librarians' book selections. School boards, courts, and library committees hold official reviews to determine whether challenged books are retained within the curriculum or offered as a choice within the school or library. Challenging and banning books has a chilling effect on teachers and librarians, but impacts all citizens' constitutional liberties (Doyle, 2017; Scales, 2016).

Trade books are a common curricular resource in the elementary grades (McMurrer, 2008). Written at various reading levels, teachers can engage diverse abilities using literature with appealing narratives and interesting characters. Scholars recognize problematic elements of gender (e.g., Chick \& Corle, 2012; Chick, Slekar, \& Charles, 2010), sexuality and identity (e.g., Bickford, 2018a; Day, 2000), the historical accuracy and representation of particular people and eras (e.g., Bickford, 2018b; Connolly, 2013; Schmidt, 2013), and within historical fiction (e.g., Schwebel, 2011; Williams, 2009). The Supreme Court's Texas v. Johnson (1989) decision established precedence opposing censorship of curricula (Goldstein, 2000). Still, literature can be a battleground in schools and libraries.

The Office of Intellectual Freedom (OIF) of the American Library Association (ALA) compiles lists of challenged or banned books using news sources, court documents, and other credible contemporaneous records. OIF and ALA generate censorship reports. Robert Doyle's (2017) Banned Books: Defending Our Freedom to Read and Pat Scales's (2016) Defending Frequently Challenged Young Adult Books: A Handbook for Librarians and Educators are two assemblages of challenged or banned books organized by year. The ALA's website reports commonly challenged books compiled by year and historically, known challenges by year and decade, by grade range, of books deemed classic by Radcliffe Publishing (n.d.), and of books with diverse themes and uncommon individuals.

The OIF and ALA websites report unsettling trends. First, there is an increasing frequency of challenges to books simply having multicultural themes and individuals. Diverse themeswhich OIF and ALA articulated as people of color and of various sexualities, identities, physical

\footnotetext{
${ }^{1}$ LGBTQ characters appeared in Jane Severance's (1979) When Megan Went Away and Susanne Bosche's (1981) Jenny Lives with Eric and Martin (originally, Mette bor hos Morten og Erik), which preceded Heather has Two Mommies. However, both Severance's and Bosche's were published by comparably obscure presses, the latter was not published in English until 1983, and neither appear to have been challenged or banned.
} 
and cognitive abilities, religiosities, and localities-generate challenges. Second, most challenged or banned books are disproportionally written by authors of color. Diverse authors evoke challenges. Third, nearly half the books Radcliffe characterized as classic have been challenged. Celebrated literature is not unscathed. Finally, book challenges are suppression attempts, not simply concerned citizens' worries. Even failed challenges generate negative, unwanted attention that may spark teachers' and librarians' reluctance.

A gap appears both in the research literature and within OIF and ALA websites. No one has examined patterns within challenged or banned books intended for the youngest readers. Early childhood, in which students learn to read while exploring the world, is especially important. Primary elementary students ( $\mathrm{K}-2)$ are impressionable and, with the smallest class sizes, receive the most direct attention (McMurrer, 2008). Internationally and domestically, parents are more involved in their children's learning in the primary grades than at any other time (Cunha et al., 2015; Wei et al., 2019). This article examines patterns within challenged or banned books intended for primary elementary readers.

\section{METHODOLOGY}

The theoretical framework originated from critical multiculturalism, gay and lesbian identity, and radical politics in children's literature. Critical multiculturalism explores power and agency within racial, class, and gender contexts to enhance social, educational, and economic outcomes for all (Botelho \& Rudman, 2009; Gopalakrishnan, 2011; Halpern, 2018). Critical multiculturalism enabled examination of whose stories are told, challenged or banned, and ignored while recognizing the resultant privileging or marginalizing implications. The Cass (1979) model of gay and lesbian identity -in which individuals progress from contemplating towards tolerating, accepting, and taking pride in an LGBTQ identity-ensured intrapersonal and interpersonal considerations. Integration of radical politics in children's literature prompted consideration of the corollaries to hegemony, particularly the manifest tensions when calls for radical change confront reactionary resistance (Mickenberg, 2006). The intersectional theoretical framework was appropriate considering the data pool.

Qualitative content analysis methods with inductive and deductive elements were employed (Krippendorff, 2013). The data pool was established using Doyle's (2017) Banned Books, a comprehensive resource on banned or challenged books, and reports from OIF, ALA, and National Council for Teachers of English. Each book's reading level was methodologically triangulated using multiple data sources. ${ }^{2}$ All banned or challenged books intended for primary

\footnotetext{
${ }^{2}$ Data originated from Advantage/TASA (Touchstone Applied Science Associates) Open Standard, Lexile, Grade Level Expectations, and Developmental Reading Assessment. These leveled reading systems are each proprietary software reliant upon a distinct algorithm to determine readability and text-complexity measuring, though weighing differently, word and sentence length, the number of words, letters, syllables, and syllable density for teachers to match books appropriate to students' ability.
} 
elementary students were located ( $n=59 ; 100 \%$ ) and included (see Appendix A - Children's Literature).

Open coding and axial coding were used (Krippendorff, 2013). During open coding, or inductive analysis, two researchers individually read each book and independently recorded observations. Patterns and anomalies that emerged during open coding were discussed and synthesized into testable codes for axial coding. During axial coding, or deductive analysis, both researchers individually reread each book to establish the testable codes' presence, absence, and frequency. To offer one illustrative example about how the inquiry's focus shifted during open and axial coding, the general queries within open coding ("What are specific passages that might create controversy?") were enhanced with specific categories (Table 2) for classification purposes. As an adult writer might encode messages young readers fail to fully decode, attention was paid to how content was included. Text-based observations enabled an inferential determination of authors' likely intent and primary elementary readers' expected interpretation. No divergent interpretations emerged during the second analysis. Content Analysis Tool (Table 1) originated from similar content analyses of children's literature (e.g., Bickford, 2018a, 2018b; Chick et al., 2010; Day, 2000).

Table 1: Content Analysis Tool

1. What year was the book first challenged or banned?

2. What is the targeted age-range?

3. What are the book's major themes?

4. What are specific passages that might create controversy? How many passages might elicit challenges?

5. Has this book won any awards?

6. How is socioeconomic status represented in the book?

7. Are diverse races and ethnicities represented in this book? If so, how?

8. What religions and cultures are portrayed? How are they portrayed?

9. Has this book been challenged/banned repeatedly?

10. Where has this book been challenged or banned?

11. Who challenged the book?

12. Are concepts of sexuality or sex education included? If so, are they implicit or explicit?

13. Were there any contemporaneous reports available on the reason for the challenge or ban?

Note: The above queries represent a condensed list from Open (1-5) and Axial Coding (6-15). 


\section{RESULTS}

Each element of the theoretical framework explores socially constructed boundaries. Critical multiculturalism recognizes privileged, marginalized, and disregarded voices. The Cass (1979) model of gay and lesbian identity ensures an intrapersonal exploration. The radical politics within children's literature extends the power dynamics of critical multiculturalism towards socioeconomic elements. Findings are reported through the optics of these theoretical elements.

Specific details about all books are included in Results for Q1-Q6 (Appendix B1) and Results for Q7-Q12 (Appendix B2). Most books were written for second graders ( $n=50 ; 85 \%$ ) with small portions intended for first graders $(n=7 ; 12 \%)$ and kindergarteners ( $n=2 ; 3 \%)$. As noted, determining reading levels, though imprecise, was established through a triangulation of diagnostic measures. While each book had at least one request for its removal, nearly half ( $n=$ 29; 49\%) were award-winning. Certain themes clearly evoked consternation even within celebrated books.

We employ the term themes, not occurrences or instances, because challenges rarely originated from a single, inappropriate word or sentence. Nearly all themes appeared on six or more pages ( $n=49 ; 83 \%)$; few had just one or two instances $(n=10 ; 17 \%)$. The themes were identified during open coding and organized into categories prior to, and quantified during, axial coding. Themes were not hypothesized prior to the inquiry.

Table 2: Themes That Likely Elicited Challenges

\begin{tabular}{|ll|}
\hline & Total (Percentage) \\
Sexuality & $21(36 \%)$ \\
Inappropriate Humor & $10(17 \%)$ \\
Ranger & $6(10 \%)$ \\
Mycial and Religious Diversity & $5(8 \%)$ \\
Death & $3(5 \%)$ \\
Racially or Culturally Insensitive & $3(5 \%)$ \\
Concerning Interpersonal Dynamics & $1(2 \%)$ \\
Evolution & $1(2 \%)$ \\
Two or More Themes & $1(2 \%)$ \\
\hline
\end{tabular}

\section{Sexuality}

Children's curiosities about human bodies, reproduction, and sexuality inspire the writing of, and challenges to, literature. Sexuality is an umbrella term for informational texts that explain human reproduction to young readers or literature that centers on non-heterosexual, noncisgender individuals whose interests may not align with traditional gender norms.

The majority of Sexuality-themed challenged or banned texts were explicit and detailed ( $n=16 / 21 ; 76 \%)$; a small portion were implicit or vague $(n=5 / 21 ; 24 \%)$. Sexuality manifested explicitly, like in Robi H. Harris's (1994) expository text It's Perfectly Normal: A Book about Changing Bodies, Growing Up, Sex, and Sexual Health and Michael Willhoite's (1990) realistic 
fiction Daddy's Roommate. The former answered common questions young learners frequently ask. The latter unambiguously narrated a fictional child's changing family dynamics when his father moves in with a male partner after his parents' divorce. Sexuality also appeared implicitly, as in Justin Richardson's and Peter Parnell's (2005) narrative nonfiction And Tango Makes Three about two male New York City penguins-lifelong partners-being given a baby penguin to adopt. Children and adult readers would likely ascertain the intent of the explicitly-Sexual books, yet young learners may not fully decode all that authors encoded in the implicitly-Sexual books.

Themes of sexual reproduction and non-heterosexuality elicited far more challenges than any other theme. No challenges appeared in books with comparable cisgender heterosexual themes. Sexuality concerns appear to originate from an interest in regulating information about human reproduction and a heteronormative worldview in which non-heterosexual charactersor those whose actions and interests do not align to traditional gender roles-are perceived as inappropriate. The reactionary responses apparent within Sexuality-based book challenges are attempts to police social boundaries; challengers sought to restrict young learners access to scientifically-accurate information and stories that humanize diverse people.

\section{Inappropriate Humor and Danger}

Inappropriate Humor, which might be more aptly-though colloquially-termed Potty Humor, was the second-most common theme for challenged or banned books ( $n=10 ; 17 \%$ ). Inappropriate Humor could be seen in the title of William Kotzwinkle and Glenn Murray's (2001) Walter The Farting Dog. Inappropriate Humor was also seen in inane, though not profane or crass, humor. Harry Allard (1981), for instance, describes the puerile antics of a family named The Stupids: "After breakfast the two Stupid kids had chores to do. Buster mowed the rug ( $p$. 8)." No swear words appeared.

Danger materialized when characters experienced peril, violence, threats of violence, or narrowly escaped death. Danger appeared in fairy and folk tales, far-fetched fiction, and realistic fiction. In Rudyard Kipling's (1986) folk tale The Elephant's Child, an elephant encounters risk while attempting to find explanations for the differing colors, shapes, and sizes of animals' body parts (“...[A]nd then they spanked him immediately and directly, without stopping for a long time" [p. 8]"). In the Steven Kellog's (1979) far-fetched fiction Pinkerton, Behave!, an armed robbery is thwarted when the clumsy, well-intentioned dog joins the commotion. The middle child in Judy Blume's (1981) realistic fiction The One in the Middle is the Green Kangaroo worries when told to break-a-leg (learning later it was a figure of speech) and when big brother yells and pushes. Some citizens want books with any Danger-even without violence or reckless behavior-removed from public libraries and public schools.

Inappropriate Humor challenges manifested from the fatuous and immature; Danger challenges emerged from excitement about hazardous situations. Though the aforementioned descriptors are synonymous with the targeted age range, numerous challenges appeared from Inappropriate Humor and Danger, which, as with Sexuality, originate from hegemonic regulation 
of what is deemed (in)appropriate for young readers. The history of radically-themed children's literature is rife with crass humor both for and from society's socioeconomically marginalized, to which patterns within Inappropriate Humor and Danger closely align (Mickenberg, 2006; Mickenberg \& Nel, 2008).

\section{Racial and Religious Diversity}

Books with Racial and Religious Diversity themes were often challenged or banned. As with Sexuality, the Racial and Religious Diversity book challengers sought to regulate young learners' access to accurate information about and humanizing stories for diverse others. Non-European cultures and non-Christian religions were targeted.

Books with African, Central or South American, and non-Christian themes were often challenged. Muriel Feeling's (1974) Jambo Means Hello: The Swahili Alphabet articulated the range of African languages, cultures, and religions. A five-year court battle resulted in banning Sharon Gordon's (2003) Cuba: Discovering Cultures, which detailed Cuba's racial history ("Today, many Cubans are descendants of the Spanish settlers. Others are descendants of black slaves who were brought to Cuba from Africa in the sixteenth century [p. 14-15]") and the origins of one of its most popular religions, Santeria, which "mixes Roman Catholicism with the religion of the Yoruba people who were brought from Africa as slaves" (p. 15). Of the challenged books with religious themes, all but one depicted non-Christian religions. Eric Carle's (1992) Draw Me A Star, though not explicitly Christian, was challenged for messages considered comparable to the Biblical creation story.

No analogous challenges or bans emerged in books featuring European cultures or Christianity. Challengers appear intent on policing literature incongruent with white, Christian normalcy and the social boundaries of acceptable identity. Critical multiculturalism and radical politics of children's literature each intend to impart onto students the ability to enact social change, which begins with recognition and inclusion of diverse others (e.g., Botelho \& Rudman, 2009; Gopalakrishnan, 2011; Mickenberg, 2006; Mickenberg \& Nel, 2008).

\section{Mysticism, Wizardry, and Death}

Mysticism and Wizardry appeared when characters engaged the occult or toyed with witchcraft. Challenges emerged even when Mysticism and Wizardry might be considered contextually appropriate, such as Halloween. Mem Fox's (1988) Guess What?, for instance, poses questions to children about a witch ('Does she mix rats' tails, toe nails, and dead lizards' scales? Guess! Yes!", p.19-20). Concerns also arose when the prose was less playful or when the narrative and imagery acted in concert to potentially distort Christianity. Eve Merriam's (1987) Halloween ABC illustrates the former ("Make this spot infernally hot, put your hate in, Satan; pass the pitchfork, please, Mephistopheles; Lucifer, Beelzebub, come when we call. The devil, the devil, the devil with it all [p. 4]!") and the aforementioned Carle's (1992) Draw Me A Star, in which an artist creates intergalactic objects like the Christian God's actions within the Book of Genesis. 
Death is a difficult topic for everyone, particularly young children. Fiction and nonfiction books that featured Death were challenged. Readers of Hansel and Gretel, Jacob and Wilhelm Grimm's (1812) iconic fairy tale, quickly recognize Death's central role. Esteemed author Roald Dahl's (1978) farcical The Enormous Crocodile was challenged when the crocodile threatened to, but did not actually, feast upon a child. Death also appeared in expository texts. Jim Henson's (1993) For Every Child, A Better World articulated for young children worldwide scarcity of food, clean water and air, shelter, medicine, and classroom education; he positions first world readers to recognize their privileges: “Every child needs food to eat but sometimes there isn't enough to go around. Every child needs clean water to drink but sometimes you have to go a long way to get it (p. 1-5)." Henson's was the only book that explicitly noted socioeconomic disparities.

Some citizens wanted children's literature with Mysticism and Wizardry or Death themes removed from public and school libraries. Mysticism and Wizardry challenges perhaps materialized over its incongruency with Christianity. Challengers want Death, a part of life, purged from young students' thoughts. Death was the bedrock of Henson's (1993) For Every Child, A Better World, which informed fortunate first-world readers how many contemporaries live, starve, and die. Radical politics within children's literature often confronts reactionary resistance (Mickenberg, 2006; Mickenberg \& Nel, 2008). Each element of the theoretical framework - critical multiculturalism, the Cass (1979) model of gay and lesbian identity, and radical politics within children's literature-empowers readers to recognize and confront interpersonal tensions, intrapersonal dilemmas, and societal or global stresses, upon which Mysticism and Wizardry and Death are grounded.

\section{Racially or Culturally Insensitive}

Racially or Culturally Insensitive themes relied on archaic and racist stereotypes and were challenged in older texts. Helen Bannerman's (1899) award-winning Little Black Sambo employed racist monikers (" $[\mathrm{H}]$ is name was Little Black Sambo. And his mother was called Black Mumbo. And his father was called Black Jumbo", p. 1-2), bigoted depictions of Africans' hair and facial features, and trickery that left an African boy naked and isolated ("And poor Little Black Sambo went away crying, because the cruel Tigers had taken all his fine clothes", p. 14). Claire Huchet Bishop's (1939) The Five Chinese Brothers contained antediluvian prejudices about Asian magic ("The first Chinese brother could swallow the sea. The second Chinese brother had an iron neck....The fourth Chinese brother could not be burned. The fifth Chinese brother could hold his breath indefinitely", p. 2) and stereotypical illustrations along with other concerning themes; it was grouped under Two or More Themes. Challenges to books with Racially or Culturally Insensitive themes sought diverse characters to be featured in culturally-sensitive ways.

Racially or Culturally Insensitive challenges, unlike Racial and Religious Diversity, emerged from resistance to racial and cultural distortion, not from resistance to diversity. Racially or Culturally Insensitive challenges are rooted in critical multiculturism. Racially or Culturally 
Insensitive themes are distinct from previously-noted themes that appear rooted in reactionary responses to authors' inclusion of diverse voices.

\section{Anomalous Themes and Multifaceted Books}

The previously reported themes appeared in multiple books generating clear patterns. Other topics, like Concerning Interpersonal Dynamics and Evolution, each appeared in a single book. Concerning Interpersonal Dynamics resulted when relational dynamics left one character marginalized. In Shel Silverstein's (1964) The Giving Tree, the single example of Concerning Interpersonal Dynamics, a boy makes increasingly challenging, self-absorbed requests for a tree who gives away nearly all meaningful aspects of herself until she is nothing but a stump. The unbalanced relationship between the tree and the boy sparked the book to be frequently challenged and banned at least once.

Other themes were anomalous. Evolution, the scientific theory explaining species' emergence and adaptations, was challenged as inappropriate. Lisa Westberg Peters's (2003) Our Family Tree: An Evolution Story explains how all species develop ("And that's the way our family stayed-generation after generation, year after year-for millions of years: tiny and round, floating in the sea [p. 7]") and are interrelated ("we became animals [p. 9]"). The only primary elementary book on evolution was not challenged for scientific imprecision, but for articulating scientific consensus about evolution in accessible ways for young learners: "Objections were raised because the book is about the scientific theory of evolution (Doyle, 2017, p. 193)." The challenge sought to regulate the dissemination of science to young learners.

Concerning Interpersonal Dynamics and Evolution each emerged in a single text. Many texts, however, were challenged for multiple themes. Challenges based on Two or More Themes is a compound of the previous nine.

Patricia Quinlan's (1994) Tiger Flowers, which explicitly intertwines death, AIDS and the accompanying stigma, homosexuality, and society's marginalization, has themes of Sexuality and Death. Joel adores his Uncle Michael whose life partner is named Peter. Quinlan's realistic fiction narrative evokes young readers' sympathy while explaining the tragedy of death:

Peter got sick. He had a disease called AIDS. Michael told me that when someone has AIDS, it's easy for them to get lots of other illnesses. Peter was sick for a very long time and then he died (p. 11).... After Peter died, Michael got sick and came to live with us. He had AIDS too. Michael said that some of his friends didn't want to be with him anymore because he had AIDS. But he told me that I couldn't catch AIDS by being near him the way I caught chicken pox from Tara (p. 14).

Bishop's (1939) aforementioned The Five Chinese Brothers, for instance, was challenged for being Racially or Culturally Insensitive and having elements of Danger. Relying on the racist misperception that people of Asian descent are indistinguishable, the brothers successfully avoid punishment. Only a small portion $(n=9 ; 15 \%)$ of the data pool contained multiple themes. 
The terms themes, as noted above, was used because most challenges did not emerge from concerning singular instance or inappropriate word. Marc Brown's (2006) Buster's Sugartime details Vermont's geography, weather, and maple syrup production. In a single sentence, Brown's central character, a rabbit, visits a family headed by two women: "Buster went to visit his mom's friends, Karen and Gillian. They had three children (p. 5)." The parent of a Houston elementary child sought to ban the book because this single sentence noted a family with two mothers.

Other books appear to have been challenged for less. Barbara Park's (1994) Junie B. Jones and Some Sneaky Peeky Spying was likely challenged for the sentence, "Only I hate that dumb, stupid, bedtime (p. 18)." Confirming details are unavailable, but this was the only passage that appeared to have any concerning aspects. Unlike Brown's and Park's texts, most themes were ubiquitous and not isolated instances.

\section{Context of Publication Date and Challenge}

Controversy is contextually contingent, yet commonly challenged themes emerged consistently. Sexuality-themed books, for instance, were first challenged in the 1970s and remain the most challenged theme. However, topics of sexual reproduction and diverse sexualities did not become contentious then; children's books rarely contained Sexuality themes beforehand. Peter Mayle's "Where Did I Come From?" (1974) and "What's Happening To Me?" (1975)— centering on human reproduction and puberty, respectively-had no peer or precedent expository texts. Leslea Newman's (1989) Heather Has Two Mommies was ground-breaking realistic fiction. Dozens of Sexuality-themed books followed Mayle's and Newman's, all of which were challenged soon after they were published. Their absence on the challenged lists beforehand does not indicate these themes were previously accepted.

Organizing the data by decade is imperfect, though illustrative. Eras, admittedly, do not start and end in ten-year increments. While shifts in social norms and values are not calendrically determined, patterns emerged when exploring Dates of Publication and First Challenge (Table 3).

While publication logically precedes first challenge, they do not sequentially appear. Many books were published long before challenged. Jacob and Wilhelm Grimm's (1812) Hansel and Gretel, Helen Bannerman's (1899) Little Black Sambo, Claire Huchet Bishop's (1939) The Five Chinese Brothers, and Theodor Seuss Geisel's, or Dr. Seuss's, Hop on Pop (1963) were each published more than a half-century before their first challenge (1994, 1956, 1994, and 2014, respectively). These four texts are anomalous for their age and continued controversy. Other recently-published books had lengthy gaps between publication date and date of first challenge. Muriel Feelings's (1974) Jambo Means Hello: The Swahili Alphabet and Steven Kellog's (1979) Pinkerton, Behave! were each published decades before their first challenge in, respectively, 1994 and 2000. 
Table 3: Dates of Publication and First Challenge

\begin{tabular}{|lll|}
\hline & Publication & First Challenge \\
Before 1960 & $3(5 \%)$ & $1(1 \%)$ \\
$1960 s$ & $2(3 \%)$ & $0(0 \%)$ \\
$1970 s$ & $9(15 \%)$ & $2(3 \%)$ \\
$1980 s$ & $12(20 \%)$ & $9(15 \%)$ \\
$1990 s$ & $13(22 \%)$ & $19(32 \%)$ \\
$2000 s$ & $15(25 \%)$ & $16(27 \%)$ \\
$2010 s$ & $5(8 \%)$ & $12(20 \%)$ \\
Note: Date of publication represents date of first publication.
\end{tabular}

Other books, particularly those with Sexuality themes, were challenged or banned nearly as soon as they were published. Harris's (1994) It's Perfectly Normal, Suzanne Lang's (2015) Families Families Families, Gayle Pitman's (2014) This Day in June, and Richardson and Parnell's (2005) And Tango Makes Three were each challenged or banned within a year of publication. (Each had Sexuality themes.) As noted, Sexuality was the most regulated theme within primary elementary literature.

Challenges, clearly, increased in the 1980 s and have continued at pace. When contextualized, this pattern is unsurprising considering 1980s American culture wars were particularly fierce regarding education, gender, and sexuality (e.g., Apple, 2014; Schoen, 2015; Symcox, 2002). The aforementioned themes, arguably, are proxy battles in the larger culture war. Further, nearly every theme can be traced-directly or indirectly-to challenges emerging from individuals occupying the political, social, or religious right. Racially or Culturally Insensitive was the only theme emergent from critical multiculturalism and the political left.

\section{Frequency and Location of Challenges}

Nearly half the books ( $n=25 ; 42 \%$ ) were challenged more than once. While most of the repeatedly-challenged books generated just a few challenges, many were challenged frequently. Recurrent challenges targeted Linda de Haan and Stern Nijland's (2002) King and King (8 times), Merriam's (1987) Halloween ABC (10 times), Newman's (1989) Heather Has Two Mommies (13 times), Richardson and Parnell's (2005) And Tango Makes Three (11 challenges in the first four years; 14 challenges in its first decade), Harris's (1994) It's Perfectly Normal: A Book 
about Changing Bodies, Growing Up, Sex, and Sexual Health (17 times), and Willhoite's (1990) Daddy's Roommate (31 separate challenges in its first decade alone). Importantly, all but one of the most-challenged primary books contained the Sexuality theme.

The challenge locations included every state, but centered primarily in schools $(n=45$; $77 \%$ ). More than twice as many were challenged or banned only in public schools ( $n=32 ; 54 \%$ ) than in public libraries $(n=14 ; 24 \%)$; a notable portion were challenged or banned in both public schools and public libraries ( $n=13 ; 22 \%$ ). No comprehensive data or evidence exists regarding challenges or bans in private schools.

Relatedly, it was impossible to determine who challenged each book as not all details were made public. Most challengers were unknown ( $n=35 ; 59 \%)$. No evidence suggests children or teenagers challenged books' appropriateness. Most challenges emerged from parents of school-age children ( $n=20 ; 34 \%$ ), but some notable challenges appeared from a school board member (e.g., Feelings, 1974) and seventy Oklahoma state legislators in a single year (e.g., de Haan \& Nijland, 2002). Doyle (2017) noted the prominence of concerned third-party organizations with dubious origins and euphemistic names. Called2Action, a Christian organization, with a mission to promote and defend their perceptions of family values challenged Park's (1994) Junie B Jones and Some Sneaky Peeky Spying; the Liberty Counsel contested Jessica Herthel and Jazz Jennings's (2014) I am Jazz about a young transgender girl's lived experience. There also appears collusion across state lines among mysterious third-party groups, like Virginia-based Parents Against Bad Books in Schools using identical language as similarly-named Texas both challenging-in the same year-Harvey Fierstein's (2002) genderbending The Sissy Duckling.

Tensions emerge when hegemony is confronted with calls for change. The aforementioned themes largely represent shifts away from white, Christian, heterosexual characters and families. Theoretical elements of critical multicultural and radical politics predict the reactionary resistance evoked by the radical change represented within some literature.

\section{DISCUSSION}

Findings are concerning for citizens who value civil liberties and the Constitution. There are also implications for teachers, librarians, and even administration who have been forced to resign for supporting a teacher's academic freedom to select curricula, like de Haan and Nijland's (2002) story King and King about two happily married young men. This section considers the patterns' significance.

Findings add nuance to patterns within the research literature. As changing representations of children's literature's non-white characters is shaped by context (Pescosolido, Grauerholz, \& Milkie, 1997), so too are the accompanying challenges. Children's authors increasingly include lesbian, gay, and transgender voices along with characters who stray from traditional gender roles (e.g., Bickford, 2018a; Cart \& Jenkins, 2006; Day, 2000; 
Kneen, 2015), yet heteronormative opposition manifests. Children's curiosities with sexual reproduction and interests using inappropriate language both appear often within, and evoke efforts to bowdlerize, children's literature (Callister et al., 2012; Coyne et al., 2012). While all the challenged books were intended for primary elementary students, none were intended to spark an actual revolution like those in Julia Mickenberg and Philip Nel's (2008) edited collection or whose radical politics Mickenberg (2006) scrutinized. Though there is an increased presence of female characters and female protagonists in children's literature (Chick \& Corle, 2012; Chick, Slekar, \& Charles, 2010), there appears no increase in gender-based challenges so long as gender is presented as binary and fixed. Findings confirm that education is politically contentious; emergent social issues are contested within curricula (Apple, 2014; Symcox, 2002).

Each author's motivation-and each challenger's worldview-cannot be determined from reading the book and limited contemporaneous evidence documenting the challenge. Challenges, however, appear to originate from a heteronormative, white, Christian normalcy that rejects diversity. Policing social and educational boundaries, challengers target books that emphasize religions that are not Christian, characters that are not heterosexual or breach of traditional gender norms, or represent countries and cultures with historical tensions with the United States, such as Cuba, Afghanistan, and Iraq. Challenges are reactionary responses to the radical change sparked when children's literature humanizes oft-marginalized groups. Gatekeepers' focus on children's literature is unsurprising as books represent a powerful pathway for youngsters to learn about the world, others, and themselves (Bishop, 1990). Societal acceptance of different religions, races, sexualities, and interests does not precede their appearance in cultural and curricular artifacts. The themes are, thus, unsurprising.

Findings have important implications for teachers, librarians, administration, parents, and citizens. First, challenges are not convictions. Many appear myopic and parochial. Each reveals a single person's or a small group's concerns. No challenge contains views of those who desperately want to see themselves or diverse others in literature. A challenge, thus, should not be considered condemnation. Second, academic freedom is as integral to education as freedomof-the-press is to journalism. Teachers should select the themes and texts upon which to focus, librarians should stock shelves to meets the needs of a pluralist democracy, and administrators must carefully listen to citizens' concerns while recognizing that not all criticisms should compel change. Third, teachers, librarians, and administration should recognize themes and literature that may cause consternation. Detailed aspects are reported in the Appendices B1 and B2. Finally, all involved-authors, school personnel, and concerned citizens-want the best for children. Recognition, and not suppression, of divergent opinions should abound. While challenges are likely done in earnest, resistance to book banning is similarly sincere. Good libraries, it has been said, contain something for everyone and something to offend most everyone (Godwin, 1992). Andrew Carnegie, a philanthropic catalyst for public libraries across 
America, argued public libraries are a cradle of democracy (Nasaw, 2006). Teachers, librarians, administration, parents, and citizens must safeguard that cradle.

This inquiry has limitations. First, oversights are possible, though two reviewers examined each book. Second, primary students' and researchers' readings might differ; a child might miss an adult author's encoded message. While two researchers worked independently, few divergent interpretations emerged. Weekly dialogue, which included shared individual analyses, perhaps minimized differing analyses. Finally, measures for reading complexity varied greatly and were identifiable in recently-published books. As such, researchers were unable to triangulate intended age of the reader for all books in the sample.

There are many potentially fruitful areas for future consideration and further inquiry. Scholars might scrutinize for themes within challenges of books intended for middle and high schoolers to juxtapose findings. It would also be enlightening to explore challenges' context (location, year, etc.) and source(s) (individual, group, etc.). Our inquiry was ex post facto and centered on content within the narratives; we did not interrogate the source and context of the challenges using contemporaneous evidence, which suggests that religiously-, politically-, or socially-conservative organizations work between states for similar purposes. As noted, Virginia-based Parents Against Bad Books in Schools and a similarly-named Texas group used identical language - and the same year - to challenge Harvey Fierstein's (2002) gender-bending The Sissy Duckling. This Virginia-Texas connection suggests an inconspicuous, insidious pattern. Using historians' methods to scrutinize extant sources, scholars might discover what content analysis of literature cannot.

As reading is fundamental, it is essential that public schools and libraries are filled with engaging texts for all ages, abilities, interests, and backgrounds. Books, to paraphrase Rudine Sims Bishop (1990), offer readers glimpses of themselves, others, and other worlds. Young learners will-and should-encounter both unimaginable and familiar characters and contexts. In a multicultural and secular society, libraries need diverse books for primary elementary students exploring the world and their place in it.

\section{REFERENCES}

American Library Association (2020, March 21). Frequently Challenged Books. http://www.ala.org/advocacy/bbooks/frequentlychallengedbooks

Apple, M. W. (2014). Knowledge, power, and education. Routledge.

Bickford, J. (2018a). Examining LGBTQ-based literature intended for primary and intermediate elementary students. The Elementary School Journal, 118(3), 409-425.

Bickford, J. (2018b) Abraham Lincoln's historical representation in children's literature and young adult trade books. Social Studies Research and Practice, 13(2), 147-167.

Bishop, R. S. (1990). Mirrors, windows, and sliding glass doors. Perspectives: Choosing and Using Books for the Classroom, 1(3), ix-xi. 
Botelho, M.J. \& Rudman, M.K. (2009). Critical multicultural analysis of children's literature: Mirrors, windows, and doors. Routledge.

Callister, M., Coyne, S., Stern, L., Stockdale, L., Miller, M., \& Wells, B. (2012). A content analysis of the prevalence and portrayal of sexual activity in adolescent literature. Journal of Sex Research, 49(5), 477-486.

Cart, M. \& Jenkins, C. (2006). The heart has its reasons: Young adult literature with gay/lesbian/queer content, 1969-2004. Scarecrow Press.

Cass, V. C. (1979). Homosexual identity formation: A theoretical model. Journal of Homosexuality, 4, 219-235.

Chick, K., \& Corle, S. (2012). A gender analysis of NCSS Notable Trade Books for the intermediate grades. Social Studies Research and Practice, 7(2), 1-14.

Chick, K., Slekar, T., \& Charles, E. (2010). A gender analysis of NCSS Notable picture book winners: 2006-2008. Social Studies Research and Practice, 5(3), 21-31.

Connolly, P. (2013). Slavery in American children's literature, 1790-2010. University of lowa Press.

Coyne, S., Callister, M., Stockdale, L., Nelson, D., \& Wells, B. (2012). “A helluva read": Profanity in adolescent literature. Mass Communication and Society, 15, 360-383.

Cunha, J., Rosário, P., Macedo, L., Rita Nunes, A., Pinto, R., Fuentes, S., \& Suárez, N. (2015).

Parents' conceptions of their homework involvement in elementary school. Psicothema, 27(2), 159-165.

Day, F. A. (2000). Lesbian and gay voices: An annotated bibliography and guide to literature for children and young adults. Greenwood Press.

Doyle, R. (2017). Banned books: Defending our freedom to read. American Library Association. Godwin, M.J. (1992). A difficult choice: Censorship or credibility. The Public Image, 4(3), 1-2.

Goldstein, R. J. (2000). Flag burning and free speech: The Case of Texas v. Johnson. University Press of Kansas.

Gopalakrishnan, A. (2011). Multicultural children's literature: A critical issues approach. Sage.

Kneen, B. (2015). Neither very bi nor particularly sexual: The essence of the bisexual in young adult literature. Children's Literature in Education, 46, 359-377.

Krippendorff, K. (2013). Content analysis: An introduction to its methodology, Third Edition. Sage.

McMurrer, J. (2008). Instructional time in elementary schools: A closer look at changes for specific subjects. Center on Education Policy.

Mickenberg, J.L. (2006). Learning from the left: Children's literature, the Cold War, and radical politics in the United States. Oxford University Press.

Mickenberg, J.L. \& Nel, P. (Eds.) (2008). Tales for little rebels: A collection of radical children's literature. New York University Press.

Nasaw, D. (2006). Andrew Carnegie. Penguin Books. 
National Council for Teachers of English (2020, March 21). https://ncte.org

Office of Intellectual Freedom (2020, March 21). http://www.ala.org/aboutala/offices/oif Pescosolido, B.A., Grauerholz, E., \& Milkie, M.A. (1997). Culture and conflict: The portrayal of Blacks in U.S. children's picture books through the mid- and late-twentieth century. American Sociological Review, 62(3), 443-464.

Radcliffe Publishing (n.d.). Radcliffe's 100 Best Novels. https://thegreatestbooks.org/lists/3 Scales, P. (2016) Defending frequently challenged young adult books: A handbook for librarians and educators. Rowman \& Littlefield.

Schmidt, G. (2013). Making Americans: Children's literature from 1930-1960. University of lowa Press.

Schoen, J. (2015). Abortion after Roe. University of North Carolina Press.

Schwebel, S. (2011). Child-sized history: Fictions of the past in U.S. classrooms. Vanderbilt University Press.

Symcox, L. (2002). Whose history? The struggle for national standards in American classrooms. Teachers College Press.

Wei, J., Pomerantz, E.M., Fei-Yin Ng, F., Wang, M., \& Wang, Q. (2019). Why does parents' involvement in youth's learning vary across elementary, middle, and high school? Contemporary Educational Psychology, 56, 262-274.

Williams, T. (2009). A closer look: the representation of slavery in the Dear America series. Social Studies and the Young Learner, 21 , 3, 26-29. 


\section{Appendix A - Children's Literature Cited}

Allan, N. (2004). Where Willy went. Knopf Books.

Allard, H. (1978). The Stupids step out. Houghton Mifflin Harcourt.

Allard, H. (1974). The Stupids have a ball. Houghton Mifflin Harcourt.

Allard, H. (1985). The Stupids die. Houghton Mifflin Harcourt.

Ancona, G. (2000). Cuban kids. Cavendish Children's Books.

Bannerman, H. (1899). Little Black Sambo. Grant Richards Publication.

Bishop, C. (Illustrated by K. Wiese) (1939). The five Chinese brothers. Coward McCann.

Blume, J. (1981). The one in the middle is the green kangaroo. Atheneum.

Brannen, S. (2008). Uncle Bobby's wedding. New York, NY: G.P. Putnam's Sons.

Briggs, R. (1973). Father Christmas. Coward, McCann \& Geoghegan.

Brown, L.K. (1997). What's the big secret? Talking about sex with girls and boys. Little, Brown, \& Company.

Brown, M. (2006). Buster's sugartime. Little, Brown and Company.

Butler, D. H. (2005). My mom's having a baby! Albert Whitman.

Carle, E. (1992). Draw me a star. Philomel Books.

Cole, B. (1993). Mommy laid an egg: Or, where do babies come from? Chronicle Books.

Crow, N. (2016). Halloween ABC. Nosy Crow Publishers.

Dahl, R. (1978). The enormous crocodile. Puffin Books.

Dahl, R. (1981) George's marvelous medicine. Puffin Books.

de Haan, L. \& Nijland, S. (2002). King and King. Tricycle Press.

Feelings, M. (1974) Jambo means hello. Dial Books for Young Readers.

Fierstein, H. (2002). The sissy duckling. Simon \& Schuster.

Fox, M. (1988) Guess what? Voyager Books.

Geisel, T. (aka Dr. Seuss) (1963) Hop on Pop. Random House.

Gordon, S. (2003). Cuba: Discovering cultures. Benchmark Books.

Grimm, J. \& Grimm, W. (adapted by Marshall, J.) 1990, Hansel and Gretel. Puffin Books.

Handford, M. (1987). Where's Waldo? Candlewick Press.

Harris, R.H. (1994). It's perfectly normal: A book about changing bodies, growing up, sex, and sexual health. Candlewick Press.

Harris, R.H. (2012). Who's in my family? All about our family. Candlewick Press.

Henson, J. (1993). For every child, a better world. United Nations.

Herthel, J. \& Jennings, J. (2014). I am Jazz. Dial Books for Young Readers.

Kellog, S. (1979) Pinkerton, behave! Puffin Books.

Kilodavis, C. (2009). My princess boy. Simon \& Schuster.

Kipling, R. (1986) The elephant's child. Alfred A. Knopf.

Kotzwinkle, W. \& Murray, G. (2001). Walter the farting dog. Frog Books. 
Kuskin, K. (1986). Dallas Titans get ready for bed. Harper \& Row.

Lang, S. (2015) Families families families. Random House.

Mayle, P. (1974). "Where did I come from?" The facts of life without any nonsense and with illustrations. Lyle Stuart.

Mayle, P. (1975). "What's happening to me?" The answers to some of the world's most embarrassing questions. Lyle Stuart.

Merriam, E. (1987). Halloween ABC. Alladin.

Mochizuki, K. (1993). Baseball saved us. Lee \& Low Books.

Newman, L. (1989). Heather has two mommies. Alyson Wonderland.

Park, B. (1992). Junie B. Jones and the stupid smelly bus. Random House.

Park, B. (1994). Junie B. Jones and some sneaky peeky spying. Random House.

Parr, T. (2003). The family book. Little, Brown, and Company.

Peters, L.W. (2003). Our Family Tree: An Evolution Story. Harcourt.

Pilkey, D. (2002). The adventures of Super Diaper Baby. Scholastic.

Pitman, G. E. (2014). This day in June. Magination Press.

Quinlan, P. (1994). Tiger flowers. Lester Publishing.

Richardson, J. \& Parnell, P. (2005). And Tango makes three. Simon \& Schuster.

Sachar, L. (1989). Wayside school is falling down. HarperCollins.

Sachar, L. (1993) Marvin Redpost: Is he a girl? Random House.

Schwartz, A. (1984). In a dark dark room. HarperCollins.

Schwartz, A. (1992). And the green grass grew all around. HarperCollins.

Sendak, M. (1970). In the night kitchen. HarperCollins.

Silverstein, S. (1964). The Giving Tree. HarperCollins.

Willhoite, M. (1990). Daddy's roommate. Alyson Wonderland.

Winter, J. (2003). The librarian of Basra: : A True Story from Iraq. Houghton Mifflin Harcourt.

Winter, J. (2009). Nasreen's secret school: A true story from Afghanistan. Beach Lane Books.

Wood, A. (1988). Elbert's bad word. Harcourt Brace Jovanovich. 


\section{Appendix B1 - Results for Q1-Q6}

\begin{tabular}{|c|c|c|c|c|c|c|}
\hline $\begin{array}{l}\text { Author \& } \\
\text { year }\end{array}$ & Q1 & Q2 & Q3 & Q4 & Q5 & Q6 \\
\hline Allan 2004 & $2000 s$ & 2nd & Sexuality & $3+$ & Yes & No \\
\hline Allard 1974 & 1990s & 2nd & Inappropriate Humor & $3+$ & No & No \\
\hline Allard 1978 & $1990 \mathrm{~s}$ & 2nd & Inappropriate Humor & $3+$ & No & No \\
\hline Allard 1981 & $1990 \mathrm{~s}$ & 2nd & Inappropriate Humor & $3+$ & No & No \\
\hline Ancona 2000 & $2000 \mathrm{~s}$ & 2nd & Racial/Religious Diversity & $3+$ & No & No \\
\hline $\begin{array}{l}\text { Bannerman } \\
1899\end{array}$ & $<1960$ & 2nd & Racially-Insensitive & $3+$ & No & No \\
\hline Bishop 1939 & $1990 \mathrm{~s}$ & 2nd & $2+$ & $3+$ & Yes & No \\
\hline Blume 1981 & $1980 \mathrm{~s}$ & 2nd & Danger & $3+$ & No & No \\
\hline Brannen 2008 & $2000 \mathrm{~s}$ & 2nd & Sexuality & $3+$ & Yes & No \\
\hline Briggs 1973 & $1970 \mathrm{~s}$ & $1 \mathrm{st}$ & Inappropriate Humor & $1-2$ & Yes & No \\
\hline Brown 2006 & $2000 s$ & 2nd & Sexuality & $1-2$ & Yes & No \\
\hline $\begin{array}{l}\text { Brown\&Br } \\
1997 \\
\end{array}$ & $2010 s$ & 2nd & Sexuality & $33+$ & No & No \\
\hline Butler 2005 & $2010 \mathrm{~s}$ & 2nd & Sexuality & $3+$ & Yes & No \\
\hline Carle1992 & 1990s & $1 \mathrm{st}$ & $2+$ & $3+$ & No & No \\
\hline Cole 1993 & $1990 \mathrm{~s}$ & $1 \mathrm{st}$ & Sexuality & $3+$ & No & No \\
\hline Crow 2016 & $2010 s$ & Nonreader & Inappropriate Humor & 1or2 & No & No \\
\hline Dahl 1978 & $1980 \mathrm{~s}$ & 2nd & Death & 1or2 & No & No \\
\hline Dahl 1981 & $1990 \mathrm{~s}$ & $2 n d$ & $2+$ & $3+$ & No & No \\
\hline de Haan 2000 & $2000 \mathrm{~s}$ & 2nd & Sexuality & $3+$ & Yes & No \\
\hline Feelings 1974 & $1990 \mathrm{~s}$ & $1 s t$ & Racial/Religious Diversity & $3+$ & Yes & No \\
\hline Fierstein 2002 & $2000 s$ & 2nd & Sexuality & $3+$ & No & No \\
\hline Fox 1988 & $1990 \mathrm{~s}$ & $1 \mathrm{st}$ & Mysticism/Wizardry & $3+$ & Yes & No \\
\hline Geisel 1963 & $2010 s$ & $1 s t$ & Danger & $3+$ & No & No \\
\hline Gordon 2003 & $2000 \mathrm{~s}$ & 2nd & $2+$ & $3+$ & No & No \\
\hline Grimm 1812 & $1990 \mathrm{~s}$ & 2nd & Death & $3+$ & No & No \\
\hline $\begin{array}{l}\text { Handford } \\
1987\end{array}$ & $1980 \mathrm{~s}$ & Nonreader & Inappropriate Humor & $1-2$ & Yes & No \\
\hline Harris 1994 & $1990 \mathrm{~s}$ & 2nd & Sexuality & $3+$ & Yes & No \\
\hline Harris 2012 & $1990 \mathrm{~s}$ & 2nd & Sexuality & $3+$ & Yes & No \\
\hline Henson 1993 & $2010 s$ & $2 n d$ & Death & $3+$ & Yes & Explicitly \\
\hline Herthel 2014 & $2010 s$ & 2nd & Sexuality & $3+$ & Yes & No \\
\hline Kellog 1979 & $2000 \mathrm{~s}$ & $1 \mathrm{st}$ & Danger & $1-2$ & Yes & No \\
\hline $\begin{array}{l}\text { Kilodavis } \\
2009\end{array}$ & $2010 s$ & 2nd & Sexuality & $3+$ & Yes & No \\
\hline Kipling 1986 & 1990s & 2nd & Danger & $1-2$ & No & No \\
\hline $\begin{array}{l}\text { Kotzwinkle } \\
2001\end{array}$ & $2000 \mathrm{~s}$ & 2nd & Inappropriate Humor & $3+$ & No & No \\
\hline Kuskin 1986 & $1980 \mathrm{~s}$ & 2nd & Inappropriate Humor & $1-2$ & No & No \\
\hline
\end{tabular}




\begin{tabular}{|c|c|c|c|c|c|c|}
\hline Lang 2015 & $2010 s$ & $2 n d$ & Sexuality & $3+$ & Yes & No \\
\hline Mayle 1974 & $1980 \mathrm{~s}$ & 2nd & Sexuality & $3+$ & No & No \\
\hline Mayle 1975 & 1980s & $2 n d$ & Sexuality & $3+$ & No & No \\
\hline Merriam 1987 & 1980s & 2nd & Mysticism/Wizardry & $3+$ & Yes & No \\
\hline $\begin{array}{l}\text { Mochizuki } \\
1993\end{array}$ & $2000 s$ & 2nd & Racial/Religious Diversity & $3+$ & Yes & No \\
\hline $\begin{array}{l}\text { Newman } \\
1989\end{array}$ & 1990s & 2nd & Sexuality & $3+$ & Yes & No \\
\hline Park 1992 & 1990s & $2 n d$ & Danger & $1-2$ & No & No \\
\hline Park 1994 & $2000 s$ & 2nd & Danger & $1-2$ & No & No \\
\hline Parr 2003 & $2010 s$ & 2nd & Sexuality & $3+$ & Yes & No \\
\hline Peters 2003 & $2000 \mathrm{~s}$ & 2nd & Evolution & $3+$ & Yes & No \\
\hline Pilkey 2002 & $2000 s$ & 2nd & Inappropriate Humor & $3+$ & No & No \\
\hline Pitman 2014 & $2010 s$ & 2nd & Sexuality & $3+$ & Yes & No \\
\hline Quinlan 1994 & 1990s & 2nd & $2+$ & $3+$ & No & No \\
\hline $\begin{array}{l}\text { Richardson } \\
2005\end{array}$ & $2000 s$ & 2nd & Sexuality & $3+$ & Yes & No \\
\hline Sachar 1989 & 1990s & 2nd & Inappropriate Humor & $3+$ & No & No \\
\hline Sachar 1993 & $2000 s$ & 2nd & Sexuality & $3+$ & No & No \\
\hline $\begin{array}{l}\text { Schwartz } \\
1984\end{array}$ & $1980 \mathrm{~s}$ & 2nd & Mysticism/Wizardry & $3+$ & No & No \\
\hline $\begin{array}{l}\text { Schwartz } \\
1992\end{array}$ & $2000 s$ & 2nd & $2+$ & $3+$ & No & No \\
\hline Sendeck 1970 & $1970 \mathrm{~s}$ & 2nd & $2+$ & $3+$ & Yes & No \\
\hline $\begin{array}{l}\text { Silverstein } \\
1964\end{array}$ & $1980 \mathrm{~s}$ & 2nd & Interpersonal Dynamics & $3+$ & Yes & No \\
\hline Wilhoite 1990 & $1990 \mathrm{~s}$ & 2nd & Sexuality & $3+$ & Yes & No \\
\hline Winter 2004 & $2010 s$ & 2nd & Racial/Religious Diversity & $3+$ & Yes & No \\
\hline Winter 2009 & $2010 \mathrm{~s}$ & 2nd & Racial/Religious Diversity & $3+$ & Yes & No \\
\hline Wood 1988 & 1990s & 2nd & $2+$ & $3+$ & No & No \\
\hline
\end{tabular}


Appendix B2 - Results for Q7-Q12

\begin{tabular}{|c|c|c|c|c|c|c|}
\hline $\begin{array}{l}\text { Author \& } \\
\text { year }\end{array}$ & Q7 & Q8 & Q9 & Q10 & Q11 & Q12 \\
\hline Allan 2004 & No & No & $1 x$ & Library & Unknown & Explicitly \\
\hline Allard 1974 & No & No & $2+$ & Both & Unknown & No \\
\hline Allard 1978 & No & No & $1 x$ & School & Unknown & No \\
\hline Allard 1981 & No & No & $1 x$ & Library & Unknown & No \\
\hline $\begin{array}{l}\text { Ancona } \\
2000\end{array}$ & Explicitly & No & $1 x$ & School & Unknown & No \\
\hline $\begin{array}{l}\text { Bannerman } \\
1899\end{array}$ & Explicitly & No & $2+$ & Both & Unknown & No \\
\hline $\begin{array}{l}\text { Bishop } \\
1939 \\
\end{array}$ & Explicitly & No & $2+$ & School & Parent & No \\
\hline $\begin{array}{l}\text { Blume } \\
1981\end{array}$ & No & No & $1 x$ & School & Unknown & No \\
\hline $\begin{array}{l}\text { Brannen } \\
2008\end{array}$ & No & No & $2+$ & Library & Parent & Explicitly \\
\hline Briggs 1973 & No & No & $2+$ & Both & Unknown & No \\
\hline $\begin{array}{l}\text { Brown } \\
2006\end{array}$ & Vaguely & No & $1 x$ & School & Parent & Vaguely \\
\hline $\begin{array}{l}\text { Brown } \\
1997 \\
\end{array}$ & No & No & $1 x$ & School & Parent & Explicitly \\
\hline $\begin{array}{l}\text { Butler } \\
2005 \\
\end{array}$ & No & No & $2+$ & Library & Unknown & Explicitly \\
\hline Carle1992 & No & Vaguely Christian & $2+$ & School & Parent & Vaguely \\
\hline Cole 1993 & No & No & $1 x$ & Library & Parent & Explicitly \\
\hline Crow 2016 & No & No & $1 x$ & Library & Unknown & No \\
\hline Dahl 1978 & Explicitly & No & $1 x$ & Library & Unknown & No \\
\hline Dahl 1981 & Explicitly & $\begin{array}{l}\text { Vaguely Non- } \\
\text { Christian }\end{array}$ & $1 x$ & School & Unknown & No \\
\hline $\begin{array}{l}\text { de Haan } \\
2000\end{array}$ & No & No & $2+$ & Both & Parent & Explicitly \\
\hline $\begin{array}{l}\text { Feelings } \\
1974\end{array}$ & Explicitly & No & $1 x$ & School & Parent & No \\
\hline $\begin{array}{l}\text { Fierstein } \\
2002\end{array}$ & Vaguely & No & $2+$ & Library & Parent & Explicitly \\
\hline Fox 1988 & No & $\begin{array}{l}\text { Vaguely Non- } \\
\text { Christian }\end{array}$ & $1 x$ & Library & Unknown & No \\
\hline $\begin{array}{l}\text { Geisel } \\
1963\end{array}$ & No & No & $1 x$ & Library & Unknown & No \\
\hline $\begin{array}{l}\text { Gordon } \\
2003\end{array}$ & Explicitly & $\begin{array}{l}\text { Vaguely Non- } \\
\text { Christian }\end{array}$ & $1 x$ & School & Parent & No \\
\hline $\begin{array}{l}\text { Grimm } \\
1812\end{array}$ & No & $\begin{array}{l}\text { Vaguely Non- } \\
\text { Christian }\end{array}$ & $1 x$ & School & Unknown & No \\
\hline
\end{tabular}




\begin{tabular}{|c|c|c|c|c|c|c|}
\hline $\begin{array}{l}\text { Handford } \\
1987\end{array}$ & Explicitly & No & $2+$ & Both & Parent & No \\
\hline Harris 1994 & Explicitly & No & $2+$ & Both & Parent & Explicitly \\
\hline Harris 2012 & Explicitly & No & $1 x$ & School & Parent & Explicitly \\
\hline $\begin{array}{l}\text { Henson } \\
1993\end{array}$ & Explicitly & No & $1 x$ & School & Unknown & No \\
\hline $\begin{array}{l}\text { Herthel } \\
2014\end{array}$ & No & No & $1 x$ & School & 3rdParty & No \\
\hline $\begin{array}{l}\text { Kellog } \\
1979\end{array}$ & No & No & $2+$ & Both & Unknown & No \\
\hline $\begin{array}{l}\text { Kilodavis } \\
2009\end{array}$ & No & No & $1 x$ & Library & Unknown & Explicitly \\
\hline $\begin{array}{l}\text { Kipling } \\
1986 \\
\end{array}$ & No & No & $1 x$ & School & Unknown & No \\
\hline $\begin{array}{l}\text { Kotzwinkle } \\
2001\end{array}$ & No & No & $1 x$ & School & Unknown & No \\
\hline $\begin{array}{l}\text { Kuskin } \\
1986 \\
\end{array}$ & No & No & $1 x$ & Library & Unknown & No \\
\hline Lang 2015 & No & No & $1 x$ & School & Parent & No \\
\hline $\begin{array}{l}\text { Mayle } \\
1974\end{array}$ & No & No & $2+$ & Both & Unknown & Explicitly \\
\hline $\begin{array}{l}\text { Mayle } \\
1975\end{array}$ & No & No & $2+$ & Library & Unknown & Explicitly \\
\hline $\begin{array}{l}\text { Merriam } \\
1987 \\
\end{array}$ & No & $\begin{array}{l}\text { Vaguely Non- } \\
\text { Christian }\end{array}$ & $2+$ & Both & Parent & No \\
\hline $\begin{array}{l}\text { Mochizuki } \\
1993\end{array}$ & Explicitly & No & $2+$ & School & Unknown & No \\
\hline $\begin{array}{l}\text { Newman } \\
1989\end{array}$ & No & No & $2+$ & Both & Parent & Explicitly \\
\hline Park 1992 & No & No & $1 x$ & School & Parent & No \\
\hline Park 1994 & No & No & $1 x$ & School & Parent & No \\
\hline Parr 2003 & No & No & $1 x$ & School & Unknown & Explicitly \\
\hline $\begin{array}{l}\text { Peters } \\
2003\end{array}$ & No & No & $2+$ & School & Parent & No \\
\hline Pilkey 2002 & No & No & $2+$ & School & Unknown & No \\
\hline $\begin{array}{l}\text { Pitman } \\
2014 \\
\end{array}$ & Explicitly & No & $2+$ & School & Unknown & Explicitly \\
\hline $\begin{array}{l}\text { Quinlan } \\
1994\end{array}$ & No & No & $1 x$ & School & Unknown & Vaguely \\
\hline $\begin{array}{l}\text { Richardson } \\
2005\end{array}$ & No & No & $2+$ & Both & Parent & Vaguely \\
\hline $\begin{array}{l}\text { Sachar } \\
1989 \\
\end{array}$ & No & No & $1 x$ & School & Unknown & No \\
\hline $\begin{array}{l}\text { Sachar } \\
1993\end{array}$ & No & No & $2+$ & School & Unknown & Vaguely \\
\hline
\end{tabular}




\begin{tabular}{|c|c|c|c|c|c|c|}
\hline $\begin{array}{l}\text { Schwartz } \\
1984\end{array}$ & No & $\begin{array}{l}\text { Vaguely Non- } \\
\text { Christian }\end{array}$ & $1 x$ & School & Unknown & No \\
\hline $\begin{array}{l}\text { Schwartz } \\
1992\end{array}$ & No & $\begin{array}{l}\text { Vaguely Non- } \\
\text { Christian }\end{array}$ & $1 x$ & School & Unknown & No \\
\hline $\begin{array}{l}\text { Sendeck } \\
1970\end{array}$ & No & No & $1 x$ & Both & Unknown & No \\
\hline $\begin{array}{l}\text { Silverstein } \\
1964 \\
\end{array}$ & No & No & $1 x$ & Library & Unknown & No \\
\hline $\begin{array}{l}\text { Wilhoite } \\
1990\end{array}$ & No & No & $2+$ & Both & 3rdParty & Explicitly \\
\hline $\begin{array}{l}\text { Winter } \\
2004\end{array}$ & Explicitly & $\begin{array}{l}\text { Explicitly Non- } \\
\text { Christian }\end{array}$ & $2+$ & School & 3rdParty & No \\
\hline $\begin{array}{l}\text { Winter } \\
2009\end{array}$ & Explicitly & $\begin{array}{l}\text { Explicitly Non- } \\
\text { Christian }\end{array}$ & $2+$ & School & 3rdParty & No \\
\hline Wood 1988 & No & No & $1 x$ & School & Unknown & No \\
\hline
\end{tabular}

